\title{
Chemical and Mineralogical Studies of Gold-bearing Rock in Iperindo, llesha Goldfield, Southwest Nigeria
}

\author{
Adetula Yomi Vincent, Ozah Blessing, Alabi Oladunni Oyelola, Marindoti Damilola Missturah, \\ John Ade Ajayi
}

Department of Metallurgical and Material Engineering, Federal University of Technology, Akure, Nigeria

\section{Email address:}

Adetula.yomi1987@yahoo.com (A. Y. Vincent), Ozah_blessing@yahoo.com (O. Blessing), Ooalabi@futa.edu.ng (A. O. Oyelola), daminic4rl@yahoo.com (M. D. Missturah)

\section{To cite this article:}

Adetula Yomi Vincent, Ozah Blessing, Alabi Oladunni Oyelola, Marindoti Damilola Missturah, John Ade Ajayi. Chemical and Mineralogical Studies of Gold-bearing Rock in Iperindo, Ilesha Goldfield, Southwest Nigeria. American Journal of Nanosciences.

Vol. 5, No. 4, 2019, pp. 43-47. doi: 10.11648/j.ajn.20190504.13

Received: October 22, 2019; Accepted: November 21, 2019; Published: November 26, 2019

\begin{abstract}
This paper provides chemical and mineralogical studies on Gold-bearing rock ore. The samples used was sourced from Iperindo at Ilesha Local Government Area of Osun state, Nigeria. 500g of the ore was weighed using digital weighing balance. The samples were crushed and ground until $80 \%$ passing of $75 \mu \mathrm{m}$ sieve. The ground ore was blended homogeneously before the analysis while for the ore microscopic study, true fraction representative gold-bearing rock samples were prepared as polished mounts and characterized using Scanning Electron Microscope-Energy Dispersive X-ray (SEM/EDX). X-ray Fluorescence (XRF) was used to determine the chemical composition while identification of the associate mineral phase was done using X-ray Diffraction (XRD) technique. From the optical microscopy and SEM/EDX study, the gold grain was found embedded in the quartz and spotted interlocked in feldspar within a microscopic size level while a fracture type of surface morphology was observed which shows a protuberant quartz-feldspar veins texture. XRD shows the mineral phases of quartz, dolomite, sylvite, annite. The traces of $\mathrm{K}, \mathrm{Ba}$ and $\mathrm{Rb}$, in this compound shows that the ore is a typical mesothermal gold deposit. Hence, the gold is finely disseminated on the silicate mineral and this characteristic is unsuitable to be processed by physical separation as the microscopic gold will tend to be lost during processing. However, a sustainable processing method such as froth flotation can be proposed to overcome this problem.
\end{abstract}

Keywords: Gold Bearing-rock, Mineralogy, Mineral Processing, Ores, Sustainable

\section{Introduction}

It has been observed that the gross domestic products of many countries of the world are directly related to the quantum of metal products produced or consumed by those nations. Nigeria is one of the countries in the world blessed with abundant solid mineral deposits [1]. It's so unfortunate that the country is highly mineralized, but backward technologically and industrially because value is hardly added to Nigeria's mineral resources [2]. Industrial raw materials are either mining or agricultural products; the former is depletable while the latter is replenishable. It behooves any nation therefore, to judiciously explore, exploit, process, extract and utilize her solid mineral resources. There are over 44 economic minerals that has been reported in Nigeria including gold ores which is predominant found in three regions, for convenience, classified as Zamfara-Malenjo in Zamafara state, Lapai- Birnin Gwari in Kaduna state and Ife-Ilesha area in Osun state. Nigeria deserves to be among gold producing nations of the world with enhanced economy because Nigeria economy cannot longer rely on petroleum. However, the country will benefit immensely from the mining and processing of its gold deposits because Iperindo lode gold ore, being one of Nigeria's gold deposits can affect our economy positively if value is added to it by way of mining and processing it efficiently. The process design of the gold bearing-rock in Iperindo will ensure sustainable solid mineral development which entails exploration, exploitation, processing, extraction and utilization of the depletable resources can be achieve if the appropriate technique to be adopted for processing the mineral deposit which depend on the mineralogy of the deposit, grade of ore, nature and 
concentration of the impurities associated with the ore is known [3]. It becomes imperative to study the chemical and mineralogical of Iperindo gold-bearing rock in llesha goldfield. Different analysis on gold ore had been carried out by various researchers using the XRF, AAS, XRD and SEM-EDX on minerals and materials containing gold. Electron microscope was used to study the microstructure of gold in Ilesha [4]. In his work, the studies of the preliminary investigation on the mineralogical of Ilesha was carried out. Also, the use of optical and electron microscopy are employed in the micron and submicron level investigation of different gold ores or materials having gold and other elements contained in them [5-9]. However, this experiment applies SEM-EDX because scanning electron microscopy reveals texture that cannot be observed by optical microscopy [10]. Other characterization carried out in this research employed the use of Atomic Absorption Spectrometry (AAS), X-ray Fluorescence (XRF), and X-ray diffractometer (XRD) in measuring the elemental content contained in the ore and the mineralogical assemblage of the ore $\mathrm{XRF}$ is chosen due to its advantage of ease of sample preparation, stability and ease of use of X-ray spectrometer [11]. The current diversification plan of the Nigerian economy to agriculture and solid minerals calls for preliminary investigations and study of the different minerals whose deposits have been proven in the country; hence, this paper focus on the chemical and mineralogical characterization of the gold-bearing rock form as it is compulsory before the gold deposit is brought to the beneficiation process. Prior to separation and extraction process of the gold, the waste mineral needs to be identified and separated physically and chemically as gangue minerals would affect the quality of final product. With a better understanding on the mineralogy of the gold, this would effectively minimize the cost of gold processing.

\section{Materials and Methods}

\subsection{Sampling and Weighing}

Gold-bearing rock ore used was obtained from Iperindo village of the Ilesha local government. The goldfield deposit site which is about 23 square kilometres, lies within latitude $7^{\circ} 3^{\prime}$ ' and $7^{\circ} 35^{\prime}$ and longitude $4^{\circ} 30^{\prime} .500 \mathrm{~g}$ of the ore was weigh using digital weighing balance after random sampling method follow by cone and quartering sampling method. This method was used because sampling is a crucial step in any gold process mineralogy study and unrepresentative samples will bias the gold assays and mineralogical gold balance due to inhomogeneous spatial distribution of gold and higher density of sulphide minerals. The samples were crushed and ground until $80 \%$ passing of $75 \mu \mathrm{m}$ sieve. The ground ore was blended homogeneously before the analysis while for the ore microscopic study, true fraction representative gold-bearing rock samples were prepared and characterized using Scanning Electron Microscope-Energy Dispersive X-ray (SEM/EDX). $\mathrm{X}$-ray Fluorescence (XRF) which is a semi-quantitative analysis tool was used to determine the chemical composition while identification of the associate mineral phase was done using X-ray Diffraction (XRD) technique.

\subsection{Chemical Analysis of Iperindo Gold-bearing Rock Ore}

The elemental analysis of the Iperindo gold-bearing rock ore was carried out using the fire assay technique. The result of the elemental analysis is presented in Table 1. Chemical analysis of the gold-bearing rock ore was carried out using the X-ray fluorescence (XRF) of the Caleb Analytical Solution Laboratory in South Africa. 20g of the Gold-bearing rock ore was pulverized to the powder form, the powdered ore was thereafter fed into the sample holder of the XRF equipment. The chemical composition of the Iperindo gold-bearing rock ore is shown in Table 2.

\subsection{Microscopy and Mineralogical Assemblage of Iperindo Gold-bearing Rock Ore}

\subsubsection{Ore Microscopy}

Ore microscopy was carried out on the Iperindo gold-bearing rock ore at the Geology Engineering Laboratory, Federal University of Technology Akure, Nigeria. The samples were cut into blocks then polished and dried before viewing on the optical microscope which was equipped with high resolution digital camera for both transmitted and reflected light. The photomicrograph of the mounted Iperindo gold-bearing sample is shown in Figure 1; Plate 1a and $1 \mathrm{~b}$.

\subsubsection{X-ray Diffractometry}

Determination of the mineral assemblage of the gold-bearing rock ore was carried out using the X-ray Diffractometer (XRD) in geoscience laboratory at University of Lagos, Akoka, Nigeria. 20g of the sample was pulverized and illuminated with x-rays of fixed wavelength. The x-rays were reflected and radiated. The intensity of the reflected radiation was then recorded. The resulting diffractogram is shown in Figure 2.

\subsubsection{Scanning Electron Microscopy}

Mineralogical characterization of the gold-bearing rock ore showing two dimensional image which reveals texture and crystalline structure was carried out using scanning electron microscope (SEM) of the Instrumentation the First Technical University Ibadan, Nigeria. SEM with one detector (secondary electron detector) was used. $5 \mathrm{~g}$ of gold-bearing rock ore sample was placed in SEM chamber and a beam of high energy electron was focused from the electron lenses towards the SEM chamber to generate a variety of signal at the surface of the $5 \mathrm{~g}$ gold-bearing rock sample. The signals generated from the electron and sample interactions generate a two dimensional image revealing the texture and crystalline structures of the gold-bearing rock at different magnifications. The micrographs obtained are shown in Figure 3.

\section{Results and Discussion}

\subsection{Chemical Analysis of Iperindo Gold-bearing Rock Ore}

The result of the elemental analysis carried out on the 
Iperindo Gold-bearing rock ore sample is presented in Table 1.

Table 1. Elemental Analysis of Bulk Assay of Iperindo Gold-Bearing Rock Ore Using AAS.

\begin{tabular}{llllll}
\hline Bulk Assay & Mn & Cu & Au & Fe & S \\
\hline$(\mathrm{ppm})$ & 29.970 & 6.880 & 4.100 & 4129.09 & 0.1590 \\
\hline
\end{tabular}

In addition, the result of the chemical analysis carried out on the Iperindo gold-bearing rock Ore using XRF is shown in Table 2.

Table 2. Chemical Composition of Iperindo Gold-Bearing Rock Ore Using $X R F$.

\begin{tabular}{llll}
\hline $\begin{array}{l}\text { Element Composition Element } \\
\text { Composition present }(\mathbf{p p m})\end{array}$ & \multicolumn{2}{l}{ present $(\mathbf{p p m})$} \\
\hline $\mathrm{K}$ & 15562.52 & $\mathrm{As}$ & 256.13 \\
$\mathrm{Ca}$ & 3699.51 & $\mathrm{Se}$ & 157.11 \\
$\mathrm{Ti}$ & 56463.06 & $\mathrm{Rb}$ & 2631.15 \\
$\mathrm{~V}$ & 492.07 & $\mathrm{Sr}$ & 78.78 \\
$\mathrm{Cr}$ & 1707.05 & $\mathrm{Mo}$ & 208.97 \\
$\mathrm{Mn}$ & 12096.46 & $\mathrm{Ag}$ & 0.56 \\
$\mathrm{Fe}$ & 282984.78 & $\mathrm{Au}$ & 103.98 \\
$\mathrm{Co}$ & 1374.97 & $\mathrm{~Pb}$ & 1003.38 \\
$\mathrm{Ni}$ & 1374.97 & $\mathrm{Th}$ & 432.38 \\
$\mathrm{Z}$ & 4507.29 & $\mathrm{~S}$ & 1549.76 \\
\hline
\end{tabular}

The elemental analysis carried out on the Iperindo gold-bearing rock ore as shown in Table 1 reveals that the ore contains 29.97 ppm Mn, 6.88ppm Cu, 4.10ppm Au, 4129.09 ppm Fe and $0.1059 \mathrm{ppm} \mathrm{S}$. The result shows that the Iperindo gold-bearing rock ore has appreciable gold content. The 4.10 ppm obtained is above the minimum value $0.69-1.37 \mathrm{ppm}$ which is prescribed for an economically worthwhile extraction [12]. The principal element present in the gold ore is iron which is shown in Table 1 and Table 2. From the result of the analysis, $282984.78 \mathrm{Fe}$ was revealed in the Iperindo gold-bearing rock. This ore conforms to the assertion made; gold occurs in ores as discrete particulates within sulphide minerals (mainly in pyrite and arsenopyrite)[13]. This also tallies with the observation that iron is present in a variety of oxide, hydroxide, sulfate, sulfide and silicate minerals [14].

\subsection{Microscopy and Mineralogical Assemblage of Iperindo Gold-bearing Rock}

\subsubsection{Ore Microscopy}

The result obtained from the ore microscopy carried out on the Gold-bearing ore is displayed in Plate 1a and $1 \mathrm{~b}$.
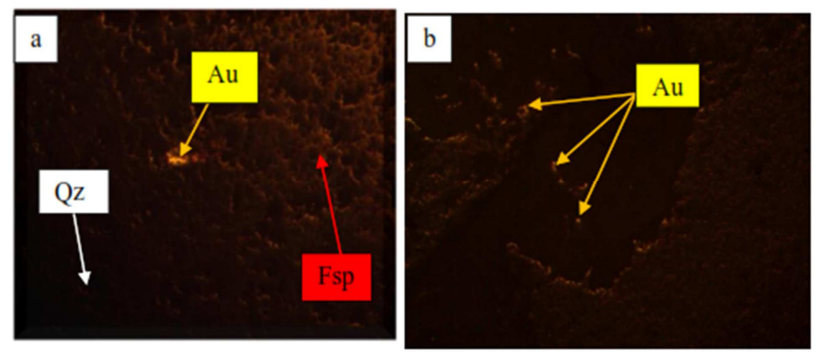

Figure 1. Photo-micrograph of Plate $1 \mathrm{a}$ and $1 \mathrm{~b}$ of Iperindo Gold-bearing Rock Ore.

Figure 1 show the microstructure of Iperindo Gold-bearing Rock Ore. This depict that the gold grain was found embedded in the quartz and also was spotted interlocked in feldspar as well within size from sub-microscopic $(1<\mu \mathrm{m})$ to microscopic $(\leq 10 \mu \mathrm{m})$ in the sulphide minerals. This result is in conformity with findings made by [15-16].

\subsubsection{X-ray Diffraction}

The minerals associated with the Gold-bearing ore in the sample obtained from the deposit is shown in Figure 1.

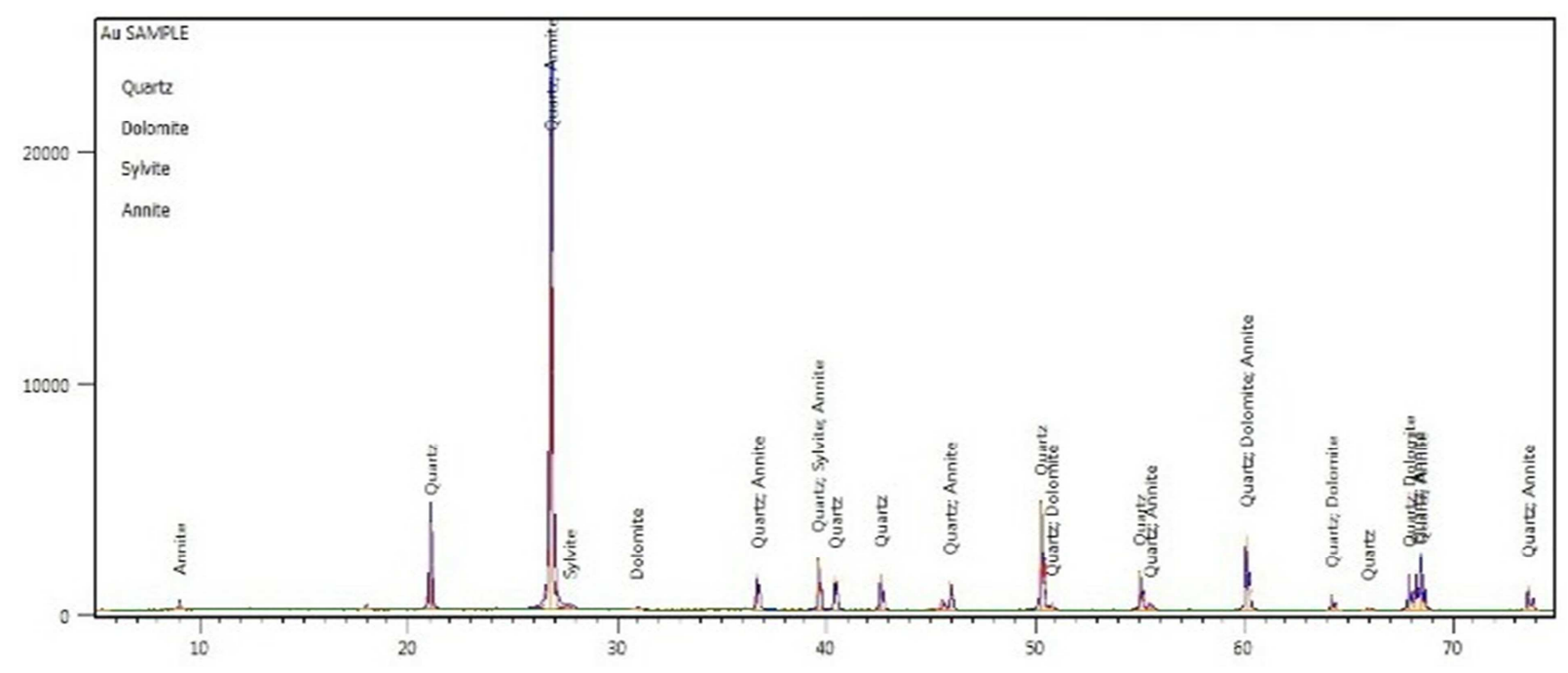

Figure 2. X-ray Diffractograph of the Gold-beraing Ore [Quartz; Dolomite; Sylvite; Annite].

As shown by the diffractogram of Iperindo gold-bearing ore, the traces of $\mathrm{K}, \mathrm{Ba}$ and $\mathrm{Rb}$, in some of the minerals/compounds like; dolomite, sylvite, annite; shows that the Iperindo gold- bearing rock ore is formed as a result of hydrothermal alteration and the host granite gneiss has been hydrothermally altered to a sericite-chlorite epidote assemblage. This characteristic indicate Iperindo gold-bearing rock ore is a typical mesothermal gold deposit as deduced by [17-18]. 


\subsubsection{Scanning Electron Microscopy}

The results of the scanning electron microscopy of the Iperindo gold-bearing rock ore determined are shown in Plates 2 and $3(a, b)$.

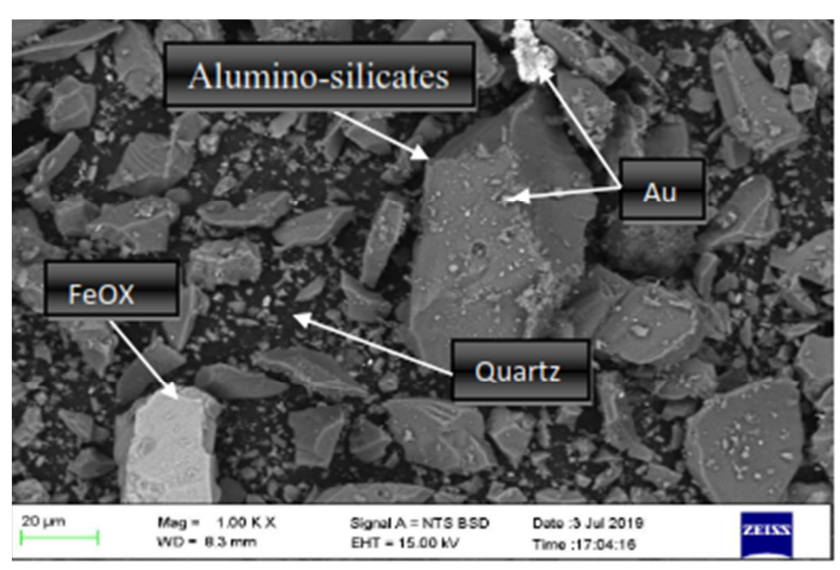

Figure 3. Scanning Electron Micrograph of Plate 2 of Iperindo gold-bearing rock ore.

The micrograph obtained from the scanning electron microscopy shown in Plates 2, 3a and $3 \mathrm{~b}$ shows the surface topography of the Iperindo gold-bearing rock ore. It shows a fracture and micro-fracture type of surface morphology and the mineralized ore comprise of highly silicified fine-grained foliated biotite gneiss typically intruded by both discordant and concordant pegmatitic quartz-feldspar veins. Another phase on the morphology revealed by the secondary electron detectors shows a protuberant quartz-feldspar veins texture which embedded a very fine gold. Plates $2,3 \mathrm{a}$ and $3 \mathrm{~b}$ conforms with the fact made by [19].
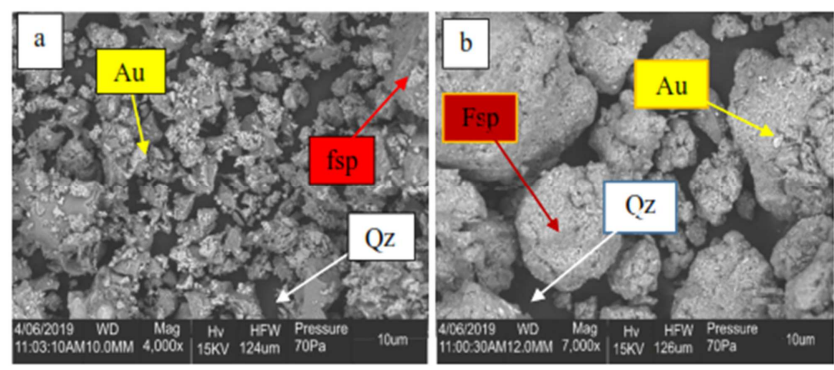

Figure 4. Scanning Electron Micrograph of Plate $3 a$ and $3 b$ of Iperindo gold-bearing rock ore.

\section{Conclusion}

From the X-ray analysis, four minerals have been identified which are quartz; dolomite; sylvite and annite. The optical microscopy and SEM/EDX study, show that the gold grain was found interlocking in quartz-feldspar vein and the gold was also found finely disseminated on the silicate mineral surface like quartz $\left(\mathrm{SiO}_{2}\right)$, annite $\left(\mathrm{Si}_{6}\right.$ $\mathrm{Al}_{7} \cdot \mathrm{Fe}_{6} \mathrm{~K}_{2} \cdot \mathrm{Na} \cdot \mathrm{O}_{24}$ ) and other mineral as also confirmed by the chemical composition present in the XRF and in SEM/EDX analysis displayed. From this mineralogical studies, gold occurs in finely disseminated quartz veins, the characteristic of the gold is unsuitable to be processed by physical separation as the microscopic gold will tend to be lost during processing and a sustainable processing method such as froth flotation can be proposed to overcome the problem.

\section{Acknowledgements}

The Author want to appreciate Dr M. O Bodunrin for his support during the characterization of the gold ore.

\section{References}

[1] Alabi O. O, Shehu A. Y, George T. D., Ferdinand A., Emmanuel T. D (2015) "Determination of Work Index of Gyel-Bukuru Columbite Ore In Plateau State, Nigeria" Journal of mineral and materials characterization and Engineering, Vol 3 pp 194-203.

[2] Adetula Y. V., Ozah B., Alabi O. O., Ajayi J. A., Akoja A. (2019) "Determination of Work Index for Iperindo Lode Gold Deposit at Ilesha Goldfield Osun State, Nigeria Using Modified Bond Index", American Journal of Materials Synthesis and Processing. Vol. 4, No. 1, pp 37-42.

[3] Hagni R. D (1978) "Ore microscopy as applied to ore beneficiation", Advances in Mechanical Engineering, Vol 10 , No. 14, pp 37-38.

[4] Ajayi J. A (2003) "Preliminary investigation on the mineralogical studies of Ilesha, (southwest Nigeria) gold ore", Journal of mining and Geology, Vol. 1 No. 37 pp 85-90.

[5] Adekola F. A., Mesubi M. A., Bello A. A., and Bale R. B, (1999) "Extraction of gold from Igun gold ore deposit in Atakumosa area, Osun state, Nigeria", Journal of Pure and Applied Science, Vol 9 No. 14, pp 936-945.

[6] Mark G., Aylmore, Kelly M., Brent I. A., McInnes, David F. S., Denis W. R, Reddy, E., Noreen and, Bradley M. (2016) "Proceedings of gold-pm sessions perth, Australia" The Institute for Geoscience Research, Curtin University Australia, Department of Applied Geology. John de Laeter Centre, Faculty of Science \& Engineering, Curtin University, Australia, ISBN: 978-0-9925094-7-7, pp 26-27.

[7] Oluwabunmi K. E., Adeleke A. A, Adetunji A. R, Jeje Abioye S. O, Adesina A. A, Ayeni F. A., and Ibitoye F. P (2014) "2k Factorial Experiments on Factors that Influence the Recovery of Gold during the Upgrade of Ilesha-Itagunmodi Gold Ore through Froth Flotation" Journal of Minerals and Materials Characterization and Engineering, Vol 2 pp. 32-39.

[8] M. G., Zagorevski, A. Devine., F. A. M., and E. Humphrey., "A new lode gold discovery at Otter Creek: Another source for the Atlin placers". In: Geological Fieldwork 2016, British Columbia Ministry of Energy and Mines, British Columbia Geological Survey Paper Vol. 1, pp. 179-193 2017.

[9] Syafiqah W. N. Anuar, Norlia Baharun and Suhaina Ismail (2018) "Significant of Gold Mineralogical Study for The Chemical Separation of Weathered Ore in Malaysia" journal of physics conferences series 1082012087.

[10] Rusk and Reed M., (2002) "Scanning electron microscope (cathodoluminescence analysis of quartz reveals complex growth) histories in veins from the Butte porphyry copper deposit, Montana," (Geology), vol. 30, No. 8, pp. 727-730. 
[11] Dehghan., G. Peterson, Riehm, and Bromerchenkel L. H., K. (2017)"Application of X-ray microfluorescence for the determination of chloride diffusion coefficients in concrete chloride penetration experiments," Constr. Build. Mater, vol. 148, pp. 85-95.

[12] Anon, (1994) U.S. Environmental Protection Agency, Technical Resource Document, Extraction and Beneficiation of Ores and Minerals, GOLD, VOLUME 2.

[13] Hausen, D. M. (1985): Process mineralogy of selected refractory Carlin-type gold ores. CIM Bulletin, Vol. 78, No. 881, pp. 83-94.

[14] Syafiqah Anuar W. N., Baharun N. and Ismail S. (2018) "Significant of Gold Mineralogical Study for The Chemical Separation of Weathered Ore in Malaysia" journal of physics conferences series 1082012087.

[15] Wang K., Zhou L. Sun Y., and Ren C. (1994) "Study on the gold occurrence from severaltypical Carlin-type gold deposits in China". Publishing House of University of Science \& Technology of China, Hefei, pp. 114.
[16] Wang K., Zhou L., Sun Y., and Ren C., (1992) SPM and SEM study on the occurrence of micrograined gold in the Jinya gold deposit", Guangxi. Chinese Science Bulletin, Vol. 37, No. 22, pp. 1906-1910.

[17] Oyinloye A. O (2006) Metallogenesis of the Lode Gold Deposit in Ilesha Area of Southwestern Nigeria: interference from isotope Systematic Pakistan journal of scientific and industrial research volume 49 No 1.

[18] Akanmu T. I., Oyeyemi O., Ayodele O. S.,(2019) Mineralogical chacterization of The Gold-Bearingnigeria Around Okemesi-Ijero Area, Southwestern Nigeria" Goblal Scientific Journal Volume 7, Issue 1.

[19] Oyinloye A. O and Steed G. M (1996) Geology and and geochemistry of Iperindo gold deposits, Ilesha schist belt, southwestern Nigeria Trans. Instn. Min. Metall. (Set. B. Appl. Earth Sci.) 105: B71-B81. 